Studia UBB 㚼igitalia, Volume 62 (LXII) 2017, December, Issue 2, 73-94

Published Online: 2017-12-30

DOI:10.24193/subbdigitalia.2017.2.05

\title{
Memories, Recollections, and Landmarks Or How I Became a Pioneer
}

\author{
Mihai Stanislav Jalobeanu \\ INCDTIM Cluj-Napoca and \\ „Vasile Goldis" Western University of Arad, Romania
}

\begin{abstract}
The paper presents a pioneering period (68-76) in the context and with the difficulties of those years remembered all of a sudden in 2006 on the occasion of the celebration of Herbert Francke in Bremen. This leaded without further explanations to a partial restart of the educational activity in the 'graphic-imagery'.

Keywords: Herbert Franke; computer graphics; computer graphics exhibitions; pioneer; computer art
\end{abstract}

\section{Instead of an Introduction}

This text has its 'roots' in an incident from October 2006. When I received a peculiar message, which I opened almost accidentally only because it included (in the Subject: line) a name which sounded familiar: "Herbert Franke".

The message came from Barbara Nierhoff, the director of the Museum of Arts in Bremen. And in this message I was asked if it was I, Mihai Jalobeanu, who once had been preoccupied with graphic arts using computers. How lucky am I that my name is not Popescu?

In Herbert Franke's archive, among hundreds of drawings, archive which was taken over by the museum and which was prepared to be exhibited, they had found two of my drawings, with dedication and signature.

Afterwards, in order to refresh my memory, they sent me an image of both drawings... And then came an avalanche of messages and questions: how did they come in the possession of Herbert Franke, what could I say about the way they had been made, 
which was my trajectory in this domain, whether I still work in this field, and, what was most amusing, why was the inscription "Worth 1 leu" on the back of one of the papers and what did that mean...

That's how the chapter closed around 1978-79 was reopened, a chapter which I considered forgotten, passed... I had to recall those years, from around 1970 to around '78-'79... that is:

- the joy of the first plotter, in the configuration of the programmable office computer HP 9100B [1], and of the graphics which I could draw with it;

- my public debut with my drawings, at the Institute of Computers, then the various exhibitions in Arad, Timișoara, București, Satu-Mare...;

- attending a conference in West Berlin and presenting some of the drawings made with the plotter and transposed into slides; followed by a visit to Erlangen, to the Siemens Computer Center, and a meeting with Georg Nees (the first European to set out in this domain in the '60s);

- the meeting with Herbert Franke, in 1974, in Bucharest, at the itinerant exhibition of the Goethe-Institute, in which he toured across Europe, explaining and promoting art made with the help of computers... On that occasion I met Professor Mocanu, the one who then succeeded in arranging my exhibition in Bucharest, in January-February of the year 1976, at the New Gallery.

Set in motion by our messages exchanged with the Director of the Museum from Bremen, I retrieved my forgotten and faded drawings from closets, photographed them and uploaded the images to my Web server from INCDTIM.

Moreover, at the university in Arad, giving account of this in the department, I found myself faced with the following cue: "Would you mind taking the 'Computer Graphics' course, as it is part of the syllabus and there is no one to teach it?"

But what is even more important is that after a quite dense correspondence with the team from Bremen, I arrived, in June 2007, at the opening of the exhibition and inaugural event called Ex Machina - Fruhe Computergraphik bis 1979 (http://www.kunsthallebremen.de/Ausstellungen), an outstanding exhibition opened from the 17th of June to the 26th of August, at Kunsthalle Bremen, a majestic building in the old port city of Northern Germany.

Kunsthalle -Bremen holds probably the amplest- collection of works of this type, and the team working on it had started a few years back a cycle of retrospective and "salvaging" expositions, with the works of the pioneers in this particular domain (Manfred Mohr, Georg Nees, Frieder Nake ...). 
The retrospective "Manfred Mohr" had still not been closed and almost simultaneously with the Ex Machina, between the 10th of July and the 31st of August, they organized the instructive exhibition called "Schule macht Kunst und macht Schule" as well.

We met there, on the 16 th of June, only 8 of us "pioneers" in the domain from the '70s (coming from Canada, Australia, UK, Romania...). At the head of us, of course, was our celebrated personality, Dr. Herbert W. Franke, lucid, modest, having a good sense of humor, in his eighties for which he was celebrated. In fact, he was the only one present there of all true pioneers who introduced art made by computers in the '60 and -'70s.

The organizers, led by Barbara Nierhoff, edited a catalog - an impressive and elegant bilingual volume of above 500 pages, published at Deutscher Kunstverlag, with the history and biography of the "pioneers", as well as a lot of reproductions... Book entitled Ex Machina - Frühe Computergraphik bis 1979, and having as a subtitle Die Sammlungen Franke und weitere Stiftungen in der Kunsthalle Bremen.Herbert Franke zum 80 Geburstag (See the cover in figure 3).

But why only until 1979? Because, with the emergence of personal computers accompanied with graphic design monitors a new phase has started, graphics with the assistance of computers becoming a more and more uncomplicated, accessible to all PC users.

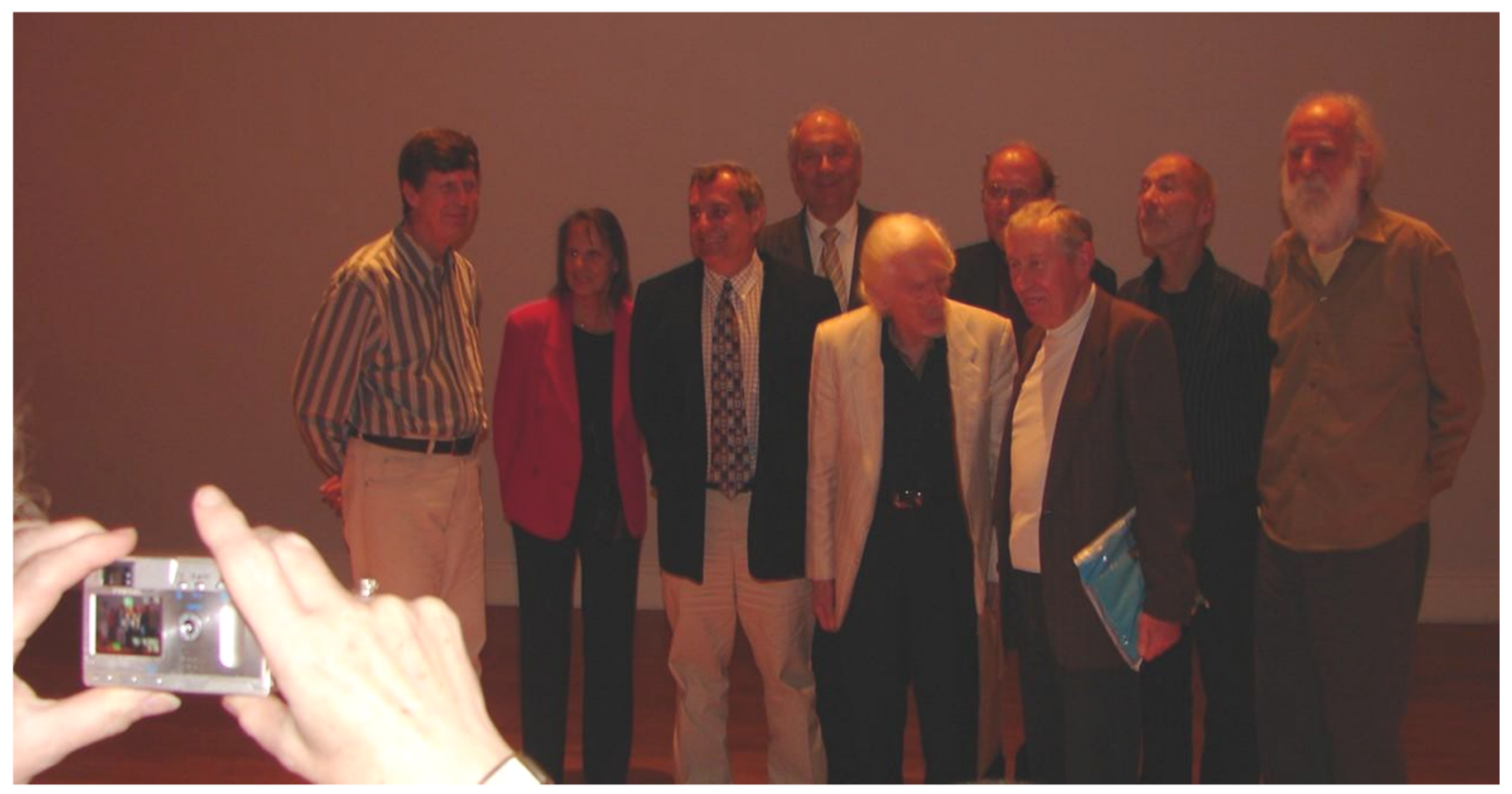

Fig. 1. The group of the "Pioneers of Computer Graphics" present in Bremen in 2007 


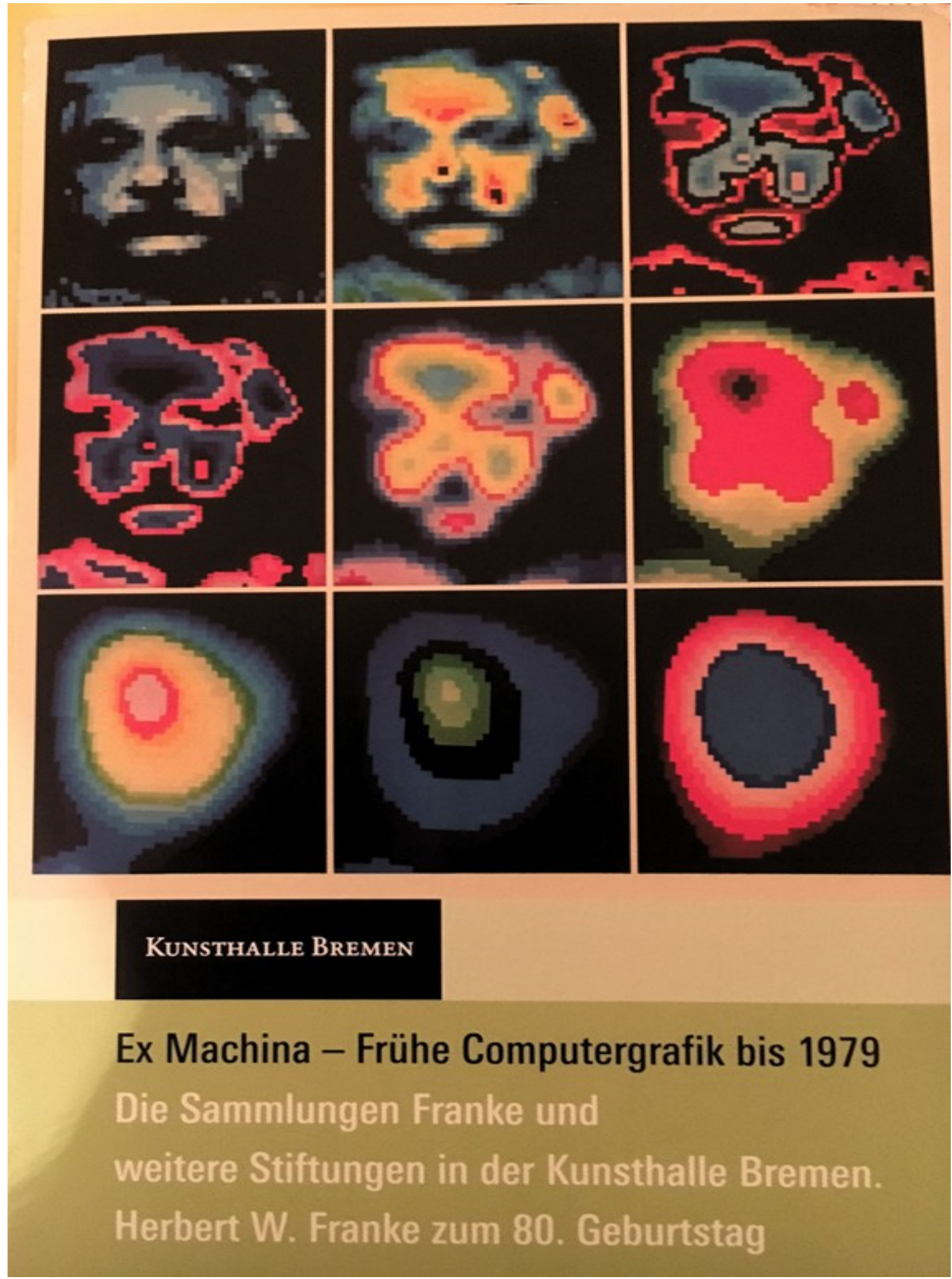

Fig. 2. The poster of the exhibition, including several reproductions of $\mathrm{H}$. Franke's works 


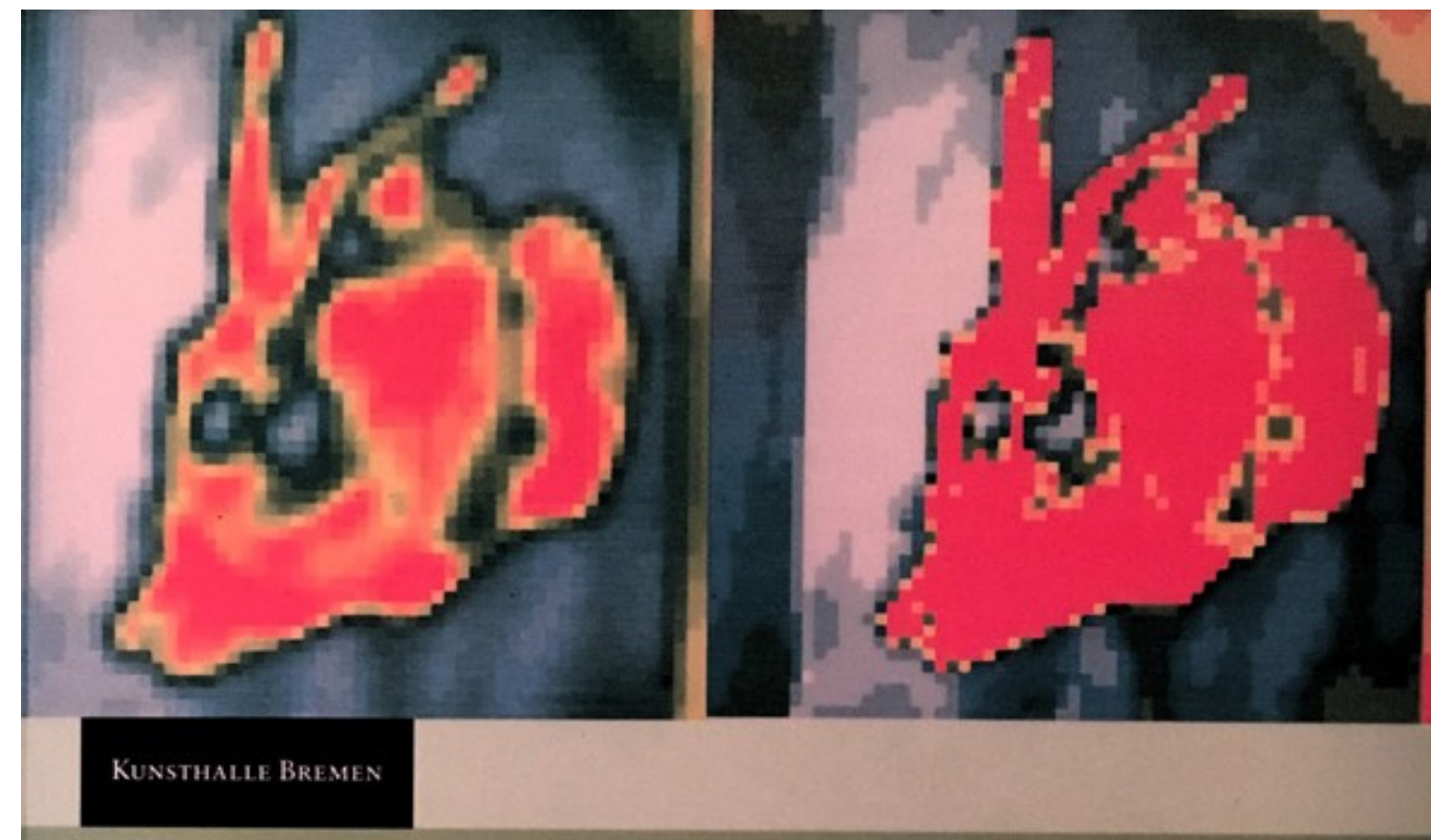

Ex Machina - Frühe Computergrafik bis 1979

Die Sammlungen Franke

und weitere Stiftungen in der Kunsthalle Bremen. Herbert W. Franke zum 80. Geburtstag

\section{Deutscher Kunstverlaa}

Fig. 3. The cover of the bilingual volume of 503 pages, elegant and dense, reproducing and explaining the context and the details of the drawings - the images featured in the exhibition as well as the few "poems" made with the help of computers in the same period (until 1979). 
Note: to the dissatisfaction of the organizers, several drawings (the drawings from Franke's archive) were untitled, thus they appear accompanied by "ohne Titel".

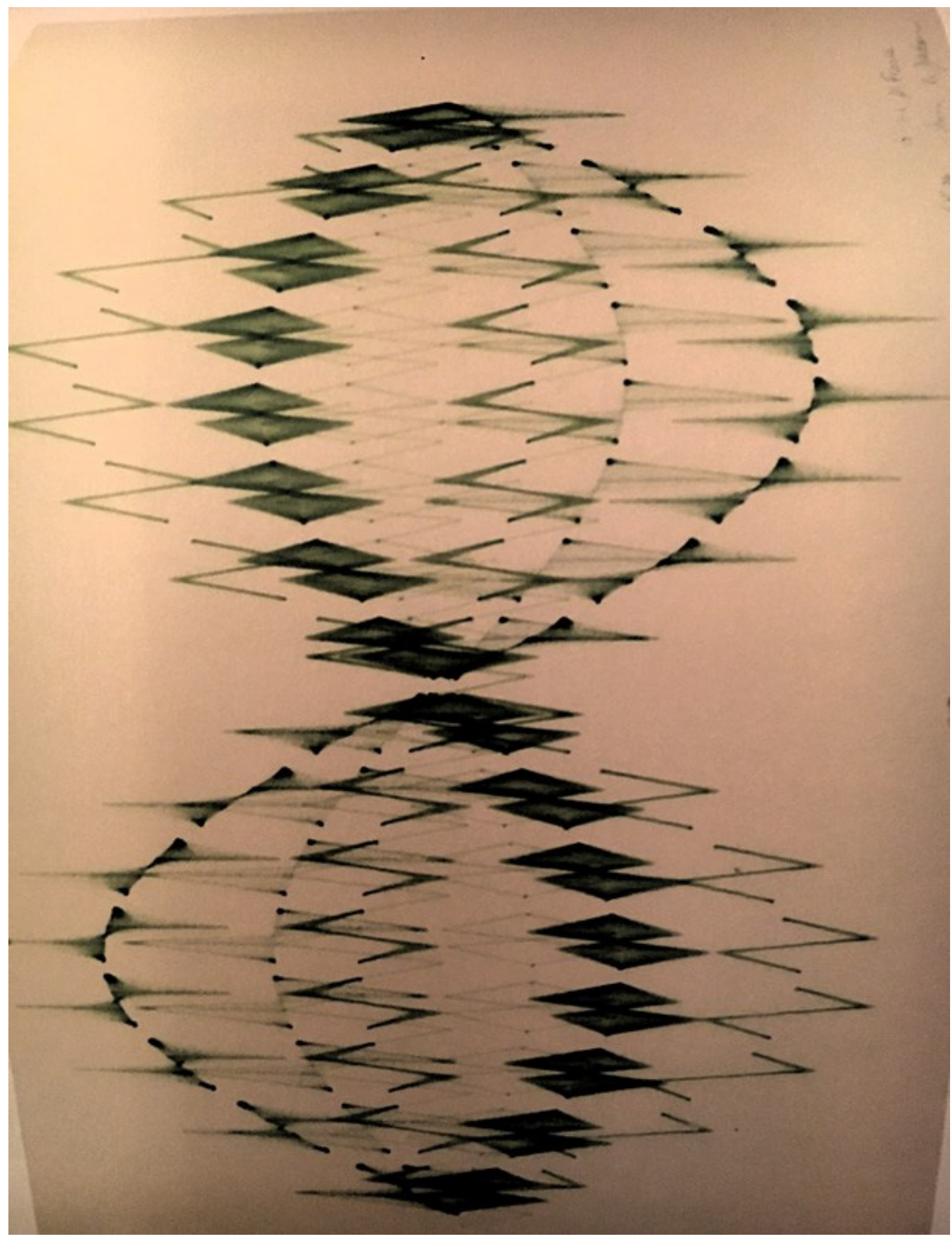

Fig. 4. Drawing which appears in the catalog (p. 196. Mihail Jalobeanu, Ohne Titel, 1974) 
During those years, to separate my artistic activity from the scientific one, I turned to this subterfuge, I signed Mihail in those kind of texts which represented my "artistic" activity, this way disassociating myself a little from the mathematician/researcher Mihai Jalobeanu.

\section{What Was the Beginning Like?}

There have been several attempts to outline the chronology of this domain, either from the point of art critique, or from that of informatics, having as context the history of computers, of informatics and of the applications in projection, publicity, film, entertainment... Some of the protagonists themselves, Herbert Franke among them, have explained and presented the appearance and the stages of the study of means in which computers could be used in art. Whayne E. Carlson designed and upheld a chronology on the Web - An Historical Timeline of Computer Graphics and Animation, replaced/ completed during the last few years through a course entitled A Critical History of Computer Graphics and Animation. Also, at the DAM::Home (Digital Art Museum), even the conclusions of the exhibition in Bremen are accessible as well, starting with Herbert Franke's "The New Visual Age: The Influence of Computer Graphics on Art and Society".

The year 1950 can be considered the starting point in the history of Computer Graphics, when the Noerbert Wiener's book entitled Cybernetics and Society (at the MIT), and when Ben Laposky, with his oscilloscope, displays some wave patterns (generated with analogical procedures) which were photographed and promoted as artistic images.

The first graphics display device (vectorscope) to the Whirlwind computer, only appeared and was presented to the public one year later.

In the years that followed, numeric computer systems are developed, the first programming languages appear, video tapes appear as well as colored television... Influenced by the oscillations of Ben Laposky, which he admired, Herbert Franke, previously specialized in photo techniques, designs his own set of images: "Lightforms" (in cooperation with Andreas Huebner) between 1953-1955, "Oscillogramm" in 1956.

Several critics of art, starting with Jasia Reichardt, consider 1956 to be the year of the birth of Computer Graphics - at that time analog (Jasia Reichardt was the Director of The Institute of Contemporary Art in London, and, in this position organized the exhibition called Cybernetic Serendipity in 1968).

The first plotters were manufactured only in 1958, drawing instruments for paper, numeric controllers, such as the CalComp 565 drum plotter... In the same year integrated circuits were invented and, independently, on an analog computer, John Whitney Senior designs his first artistic images. 
In 1959, the Museum of Modern Art in Vienna presented the exhibition "Experimentale Asthetik" which included photographs featuring Laposki's oscillations among other works made using analog computers.

\section{Graphics with the Digital Computer}

The term "computer graphics" appears only in 1960, brought to light by William Fetter, at Boeing, for his drawings that analyze the position of the pilots in the cockpit of the plane. 1960 is the year when John McCarthy enhances the LISP language and the DEC firm build-generates the first mini-computer, the PDP-1.

The year 1961 gives rise to Spacewar, the first ever digital computer game to be available outside a single research institute, created by Steve Russell at MIT, especially for PDP-1.

In 1963, Charles Csuri and Michael Noll, independently, engage in the first artistic works with the digital computer (computer generated artwork), mainly printer graphics. At MIT, Robert already starts the study of hidden line algorithms. Also, Edward E. Zajac, from Bell Labs, USA, performs the first movie ever commenced by a computer. Soon after, the Computers and Automation Journal establishes the leading art competition with a computer, which was won by Michael Noll in 1965, and by Frieder Nake, in 1966.

Also in 1963 Ivan Sutherland, an MIT programmer, and one of the pioneers of the Internet, concludes in his doctoral thesis (lead by Claude Shannon) the Sketchpad program- a system of graphic communication coupled with the computer- a very first version of graphical interfaces (a system he was working on since 1961) - achievement which was awarded in 1988 the Turing award. It is said that his work was inspired by the Memex from "As We May Think" by Vannevar Bush.

In 1968, Ivan Sutherland in association with his student Bob Sproull at Harvard, put together the pristine system of virtual reality. On the strength of this system, Sutherland is considered to be a "parent" of this innovative computer graphics. Even though the mousea common input method for most modern computers- was also invented in 1963 (by Doug Englebart), Sketchpad, and most other innovations of that time did not use it.

\section{The First Exhibitions}

In February 1965, George Nees coordinates the first computer graphic exhibition "Generative Computergrafik" at Technische Hochschule in Stuttgart, Germany. Born in 1926, George Nees studied mathematics, physics, and philosophy in Erlangen and Stuttgart, with his leading doctorate called "Generative Computer Graphics" under Max 
Bense. Nees was a professor at the Erlagen Univeristy and worked at Siemens Research and Calculation Center in Erlangen.

Similarly, in 1965 between 6-24 April the first art exhibition takes place in the United States, at Howard Wise Gallery in New York, "Computer generated Pictures" where Bela Jules and Michael Noll bring their work to light. Between 5-26 November, "Computergrafik" exhibition is being unfolded, presented by Max Bense.

George Nees, Herbert Franke and Frieder Nake are nevertheless the first ones in Europe - the European pioneers of computerized art.

In 1967, plastic surgeon Robert Rauschenberg and engineer Billy Kluever (from Bell Labs) establish a work group called "Experiments in Art and Technology" in New York (E.A.T.).

\section{Organizations and Publications}

The first Computer Graphics Chair was set up in 1968 at the University of Utah in the Computer Science department. 1969 marks the establishment of the SIGGRAPH professional organization, and Alan Kay's creation of Xerox's first Graphical User Interface (GUI).

In 1970 Lillian Schwartz produces a series of works made famous with the name Pixellation, at Bell Laboratories. At Renault factories, Pierre Bezier discovers and represents the first class of shapes and curves that now bear his name.

In 1971, the academic journal "Interactive Graphics for Computer-Aided Design" published by Prince's publishing house made its debut.

The first stereotypical workgroup in this field is organized by the SIGGRAPH section of ACM in 1972, with the name Graphics Standards Planning Committee. The same year, 1972, brings for the first time, from Utah, a system for film production, through two famous animation sequences: the movement of the hand [Catmull72] and the human face movement [Parke] respectively.

In the same year a Graphics Symposium (GRASS) system and a Sandin Image Processor appear. Academic year 1972 marks the launch of Academic Press of Computer Graphics and Image Processing, a successful publication that will become "Computer Graphics, Vision and Image Processing" in 1982, followed by the 1990's event, when it was launched in three distinct magazines.

The first major conference of this interface area takes place in 1973 in Boulder (the first SIGGRAPH conference). At Syracusse, Rich Riesenfeld introduced in his doctoral thesis approximation with b-splines in geometric design [Riesenfield]. It is the year in which the first treaty is published - the milestone volume "Principles of Interactive Computer Graphics" by Newman and Sproull. 
In 1974, (probably) the first animation company "Motion Pictures Product Group" was founded, but also a professional laboratory (CGL) at NYIT, having Ed Catmull as director. The "Hunger" film, made in Canada, receives the special jury prize for animation at the Cannes Film Festival.

In 1975 Benoit Mandelbrot, at IBM, introduces fractals, and Ed Catmull publishes a curved surface rendering algorithm [5].

In 1976, the year when Apple's PCs were launched, Computer Graphics Newsletter, which will become, two years later, Computer Graphics World, is first published. Also there are two reference books: Artist and Calculator by Ruth Leavitt, and Mathematical Basics of Computer Graphics by David Rogers. Jim Clark publishes the hierarchical pattern for visible surfaces detection [6] and Jim Blinn sets up another important algorithm for creating images in virtual reality, which he will publish in 1977 [5].

In 1977, the visual effects produced by the computer are accepted as a category for the Oscars. Also, SIGGRAPH CORE Graphics is published and developed by Jim Folley. The GKS (Graphical Kernel System) standard is introduced.

1978 marks the launch of R. Greenberg's Superman movie with CGI technique, and the emergence of Computer Graphics World on the market. Maybe even more importantly, James Blinn produces a first series of the animated cycle The Mechanical Universe that can be considered the first serious electronic course, the true beginning of what we call e-Learning today.

\section{But Who is Actually Herbert W. Franke?}

Very briefly: an illustrious model of an interdisciplinary researcher, passionate mathematician, chemist and doctor in physics, uninterested in academic positions and titles, with an up-and-coming journalistic activity. He consistently promoted the introduction of technology in art as well as in the Natural Sciences and literature. A modest man, but a central figure in European computer art; but unfairly neglected by American historiography. Born in Vienna in 1927, he studied Physics, Mathematics, Chemistry, but also Psychology and Philosophy at the University of Vienna, finishing with a PhD thesis in electronic optics in 1950. After a short research internship at the Technical University of Vienna (in which he discovers a new method of geological dating with radioactive isotopes - carbon 14, immediately after Libby), he goes to industry, to Erlangen, working until 1957, especially in the area of experimental photography. In 1957 he becomes a freelancer, settling down in Bavaria near Munich, working as a journalist and scientific consultant and entering many research fields ranging from theoretical chemistry to experimental aesthetics and speleology. Since then he has been writing intensely, and 
the list of published volumes is impressive, encompassing treaties, popularization books, and successful SciFi novels. Occasionally he has taught courses in Photography and Art, Cybernetics and Information Theory, Aesthetic Cybernetics, Computer Graphics and Art, or introduction to SciFi literature and introduction to Psychology of Perception.

His research activity also appears on at least three major directions: Aesthetics, Informatics, Geo-Physics; coordinating a research group in the aesthetics assessment (1974), studying image memories, analyzing the widespread application of miniature graphics programs, and animating curves and mathematical forms, while also taking part in climate reconstruction studies and speleological research.

In December 1974 he visited Bucharest, presenting the Goethe-Institute exhibition entitled "The Paths to Computer Art", an exhibition by K.C. Schröder under the aegis of the Göthe Institute in Munich. Herbert Franke had edited the catalog of the exhibition, choosing Leibnitz's 1702 article about binary arithmetic, and selecting the most suggestive images in the exhibition. He included there, for the promotion of German culture, Konrad Zuse's attempts to reinstate his father's contribution to the history of computer science. In other words, he presented the history of computers totally different from the official one at that time. The chapter titled "Art computer" in that catalog was even signed $<$ Herbert Franke>. For many years this catalog was for me the main source to learn about the art of the computer. Even in 1973 I had the already the chance to meet Georg Nees (another important European pioneer in the field). It happens in my short visit in Erlangen; after my participation at a youth conference in (West) Berlin, presenting by dia-films few of my first HP plotter drawings...

\section{And?}

One might say that this text is simply because I met and then listened to Dr. Herbert W. Franke in Bucharest, and he kept the drawings that I allowed myself to give them to him. Undoubtedly, my attendance to the 16th of June event in Bremen, my presence in the exhibition and its catalog are linked, over the years, with the meeting with Herbert Franke in Bucharest, and with the fact that I dared, under the conditions of 1974 , to hand him the two sheets.

But my whole involvement in computer graphics is primarily due to the concern for the interdisciplinary research inspired by Professor Elena Popoviciu and, above all, to the way she looked and discussed with Tiberiu Popovici, in 1971, at the seminar at the Institute of Computing, my first plotter drawings. For me, from there, in the seminar room at the Cluj Computer Institute, I started to be involved in "computer graphics".

Today a 'Computer generated Pictures' search leads to over 4 million results! But with the equipment at that time, with the resistance of those years even when 
using the computer in scientific research, making drawings with him seemed almost an abuse here in our areas.

Then, in the 1970s, it was not easy, I received a lot of observations and penalties because I was staying in the lab over the program, rubbing the HP 9100B desktop computer and its plotter, consuming materials and electricity to smear some sheets of paper, not even related to the theme of the institute. Then I had to find all sorts of solutions to replace/rebuild wasted consumables (especially the felt nibs and the ink which I used to make the drawings).

My luck was that the Institute's director, Professor Victor Mercea, had become enthusiastic, admired what I could do and supported me (including traveling to the FGR at the West Berlin conference), and even managed to find an "outlet" - a use of my drawings when decorating ceramic objects. In other words, he negotiated a contract with the research service of the CERO manufactory in Cluj, regarding especially the decoration of ceramic products with computer graphics. Thus, drawings made with the computer got on cups, plates and porcelain vases, not only on the market, but also in some exhibitions through the country and neighboring countries. In addition, under the wings of this practical application, I wrote and published 2 papers - 2 chapters in the Computer Graphics section of the volume Semiotics Mathematics of Visual Arts [1, 2]. In the second part, I co-sponsored my then director, to whom I also owe the researcher's career.

In closing this chapter of my work, I also want to mention the gratitude I owe to all those who, in those years, encouraged me and helped me, who were enthusiastic or criticized, looking at / analyzing my drawings. Besides the reluctant teachers already mentioned (Tiberiu Popovici and Victor Mercea), I cannot miss Prof. Titus Mocanu (who did not leave until he put together my Bucharest exhibition). And I cannot forget the deceased friends: Liliana Bocu, Mircea Țoca, Dumitru Vonica (each contributing in those years with their suggestions and enthusiasm to my artistic digression).

And one more thing: in 1990, when I considered this chapter of my life closed long ago, I was suddenly asked by a person I didn't know personally - a teacher from the Institute of Fine Arts in Cluj, to deliver course on the use of computers in art there. Explanation: In the euphoria of that winter (1989-1990), the students in the terminal year, being a part of the board of the institution, decided that they could not leave the faculty as long as they did not have a course on the role of technology in the plastic arts, and therefore did not learn anything about computer-graphics. There (is?) no one else in the area with this "expertise". What could we do? We have accepted, prepared and (supported?) delivered for almost 3 years a course on the possibilities of using computers in art. (Especially because the staff from Conservatoire "Gh. Dima" heard about it and ask my also; consequently had to go from graphics with the computer to computerized music also.???) 
Thank God that I had students who, after graduating, could take over and carry on those courses. Not for another reason, but from '94 -'95 I was passing through the barricade of connecting and promoting access to the Internet, connecting (with such efforts) the Institute of Isotopic and Molecular Technologies and, especially, organizing from 1997 to 2001 the annual seminars "RILW - "Romanian Internet Learning Workshop" to promote the use of the computer network, i.e. the Internet in training. So for Professor Oleg Aramă (former member of the Institute of Computing) I became "the pioneer of the Cluj Internet".

In 2006, when this writing started, I became a computer science professor at "Vasile Goldiş" University of Arad, so Professor Tiberiu Popovici's place of birth. A good opportunity to remember the few trips organized there in Arad by the Institute of Computing; good moments then for my outings in the world with computer graphics. All the more so since I found out that there, at the Arad House of Culture, were quite a lot of my works exposed 30 years ago. But it was also a good opportunity to try to re-bring the memory of the professor in the attention of people who live in Arad, to struggle to baptize the amphitheater in which I held the computer courses with his name.

And still there, in Arad, at the university where I became a computer science teacher, as a result of the new title of "fresh pioneer", I had to accept to teach also the "Computer Graphics" course; a course that was then in the syllabus, but "pushed" in the last semester of the last year because of the lack of specialists.

It has become my first course in virtual laboratories, and we have been using virtual groups on other courses [5,6]. Namely delivering a 'Computer graphics and Image Processing' course. Also a good occasion to organize some competitions and few digitalphotography exhibitions with my best students.

\section{References and Bibliographical Landmarks}

[1] M. Jalobeanu, „Imaginile: Producerea și prelucrarea lor cu sistemele actuale de calcul”, in „Semiotica Matematică a Artelor Vizuale” Editura Științifică și Enciclopedică, București, 1982 (edited and coordinated by prof. Solomon Marcus), pp.289-314

[2] Adriana Dobra, Mihai Jalobeanu, Victor Mercea, „Metode noi de decorare a obiectelor ceramice folosind grafica de calculator", in „Semiotica Matematică a Artelor Vizuale” Editura Științifică și Enciclopedică, București, 1982 (edited and coordinated by prof. Solomon Marcus), pp. 275-288

[3] V. Baltac (coordonator), "Calculatoarele Electronice, Grafica interactivă și Prelucrarea Imaginilor”, Editura Tehnică București, 1985; M. Jalobeanu - Capitolul 9: „Prelucrarea imaginilor, cu aplicații în medicină, biologie, robotică”, pg. 223-267

[4] Kunsthalle Bremen, „Ex Machina - Frue Computergrafik bis 1979” Die Sammlungen in der Kunsthalle Bremen. Herbert W. Franke zum 80. Geburtstag. Deutscher Kunstverlag 
[5] M. Jalobeanu, „Teaching computer graphics with virtual groups and virtual laboratories”, 6-th edition of „eLearning and Software for Education”, Bucharest, 2010

[6] M. Jalobeanu, „Web-based Teaching of Computer Graphics to Undergraduate Students", REV2011-Contribution165.pdf

[7] James F. Blinn, „Models of light reflection for computer synthesized pictures”, in Proceedings of the 4th annual conference on Computer graphics and interactive techniques July 1977, V11, \#2, pg. 192-198

[8] Wayne E. Carlson, "CGI Historical Timeline", last-updated: 2017

[9] Edwin Catmull, A System for Computer Generated Movies. Proceedings of the ACM National Conference August 1972, p. 422-431

[10] Edwin Catmull, Computer Display of Curved Surfaces. Proceedings of the IEEE Conference on Computer Graphics, Pattern Recognition and Data Structapures (IEEE Cat. No. 75CH0981-1C) 1975, p.11-17

[11] J.H. Clark, Hierarchical geometric models for visible surface algorithms. Communications of the ACM, 19(10):547- 554, 1976

[12] Herbert W. Franke, "Phänomen Kunst", Heinz Moos Verlag, München 1967

[13] Herbert W. Franke, "Computer Graphics - Computer Art", Phaidon, 1971

[14] Herbert W. Franke, "Apparative Kunst. Vom Kaleidoskop zum Computer", DuMont Schauberg, Köln, München, 1973

[15] Herbert W. Franke, "Animation mit Mathematica", Springer 2002

[16] Ruth Leavitt (Ed.), "Artist and Computer", Harmony Press, 1976

[17] Wofgang Lieser et al., "Digital Art Museum", http://www.dam.org/, viz.24.08.07

[18] Frederic I. Parke, Computer Generated Animation of Faces. Proceedings of the ACM National Conference August 1972, p. 451-457

[19] Frank Popper, "Art in the Electronic Age", Harry Abrams, New York, 1993

[20] Jasia Reichardt, "Cybernetic Serendipity", Praeger, New York, 1968

[21] Jasia Reichardt, "The Computer in Art", Studio Vista, London, 1971

[22] R.F. Riesenfeld, Applications of B-Spline Approximation to Geometric Problems of Computer Aided Design. PhD Dissertation, Syracuse University, 1973

[23] Lillian Schwartz and Laurens Schwartz, "The Computer Artist's Handbook", WW Norton, 1992

[24] Anne Morgan Spalter, "The Computer in the Visual Arts", Addison Wesley, 1998

[25] Ivan E. Sutherland, Sketchpad: A Man-Machine Graphical Communication System, Proceedings of the AFIPS Joint Computer Conference Washington D.C.: 1963, p.329-346

[26] S. Todd and W. Latham, "Evolutionary Art and Computers", Academic Press, 1992 [27] J. Whitney Snr., "Digital Harmony", McGraw-Hill, Peterborough, NY, 1980

[28] Mark Wilson, "Drawing with Computers", Putman / Perigee, 1985 


\section{Extension - But How, With What Kind of Computers Did I Work/Draw?}

In 1969, after three years in which I was still calculating and programming in the code used in DACICC-1, then in Fortran, at DACICC-200, with programs on perforated tapes, I found myself with a small and friendly programmable office computer, the "HP 9100B".

I have not been able to find out who and how was it ordered, by what means, for it was, for those years, a jewel ... produced by Hewlett Packard, the newly launched model.

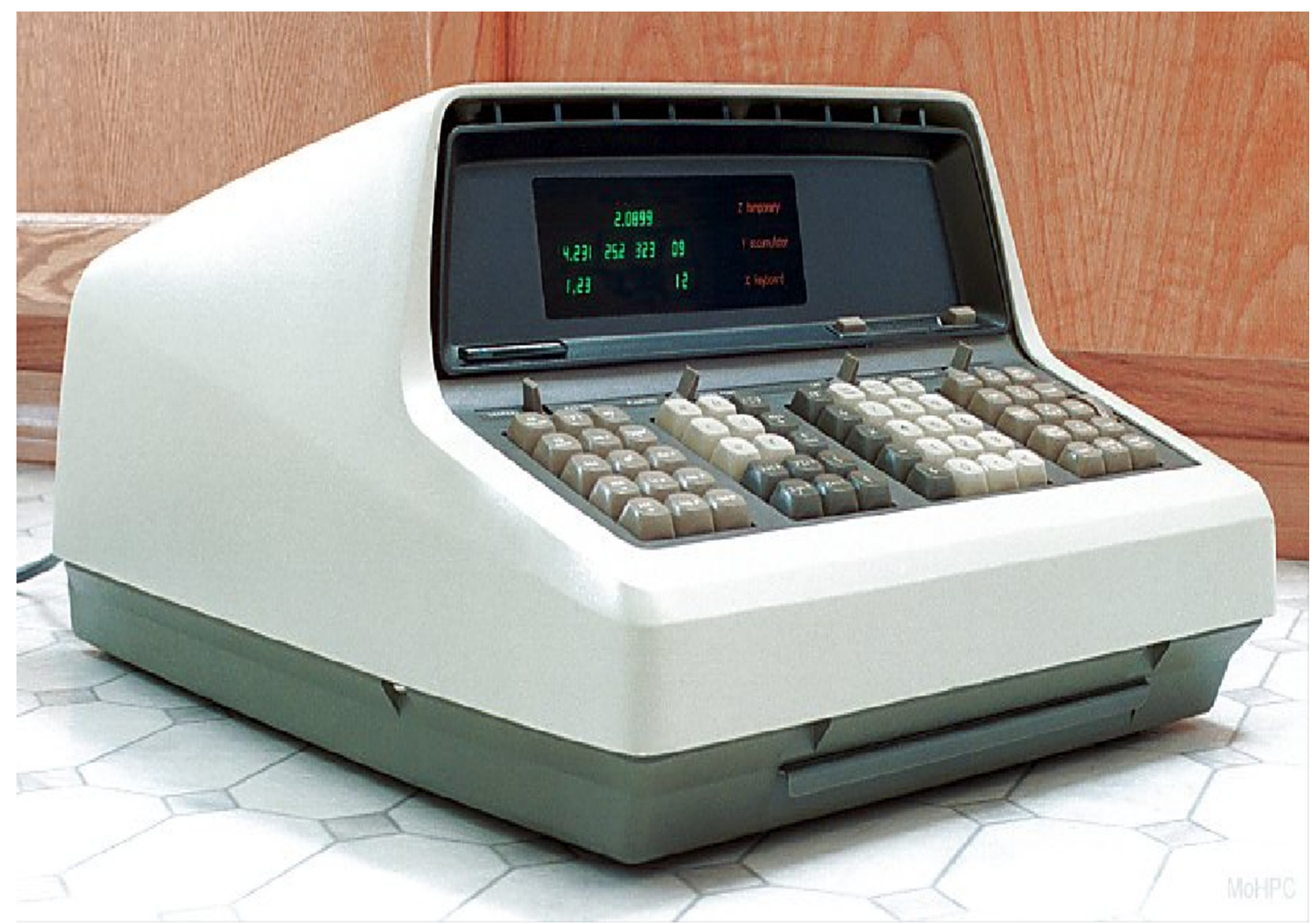

I had just begun to discover their commands, operating mode, when I also received the drawing device, that is, the attachment of the apparatus, a two-dimensional flat plotter (in the terminology of these "peripherals". It had a complex set of commands, it could be used in "manual" mode, commanded as well as in the "programmed" mode - that is, with the string of stored commands, which can be recorded even on magnetic cards, and is therefore successfully usable in the processing of experimental data. The drawing device as in the picture above used a personal distinct "pencil" system. 
As you may find now with a simple google-search, Hewlett Packard 9100B Programmable Electronic Calculator "was the second calculator made for sale by Hewlett Packard. HP's first electronic calculator, the revolutionary 9100A was introduced in the fall of 1968, with the 9100B introduced in fall of 1969."

Quite soon after the minicomputer, just wen I became more-or-less familiar with its operating system, the graphical device HP9125 plotter arrived in my lab.

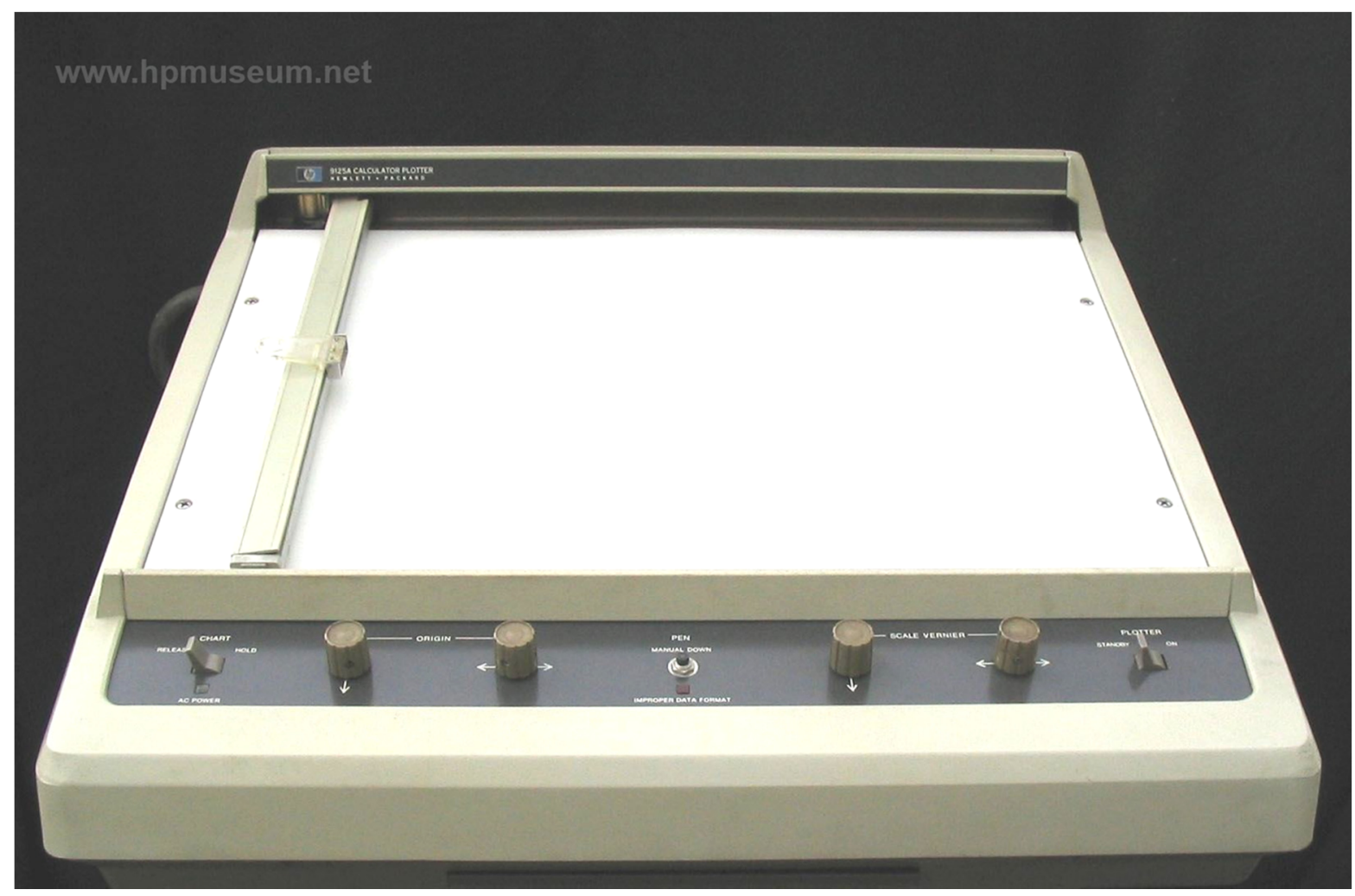

This drawing device (namely a pen-plotter) launched in the market at 1969. This was the main executor of my computer graphics drawings, and consequently a lot of my drawings are signed with a combination of our initials (ex. MJ + HP).

Unfortunately, after 9 years of quite intensive use, without the usual maintenances, without access to the corresponding market, this great mini-system became unusual. My attempt to continue "the adventure into computer graphics world" using a NOVA $3 / 12$ computer connected with a Calcomp drum plotter was unsatisfied.

But professor Victor Mercea, director of the institute, succeeded in those dark period to find "an application" for my already done computer graphics: the decoration of ceramic products, a cooperation with "CERO" Cluj institute. Namely with ceramic object designer Adriana Dobra. Consequently selecting some of already done computer graphics for decoration of bolls, plateau, etc. 
As a result, another exhibition with those decorated objects, and more important, a new chapter in a published volume; my only paper coauthored with my professor and boss, into a volume coordinated by professor Solomon Marcus. Unfortunately, those decorated object became more perishable as computer drawings.

Some of my exhibited successful drawings already saved trough photo device, could be seen at the following annex. While some more comments and other details regarding the context, and different computer-graphics exhibitions in Romania between 1970-1989 are now available trough Internet, especially at Monoskop (http://monoskop.org).

\section{ANNEX - A small selection from my drawings realized with HP system those years}

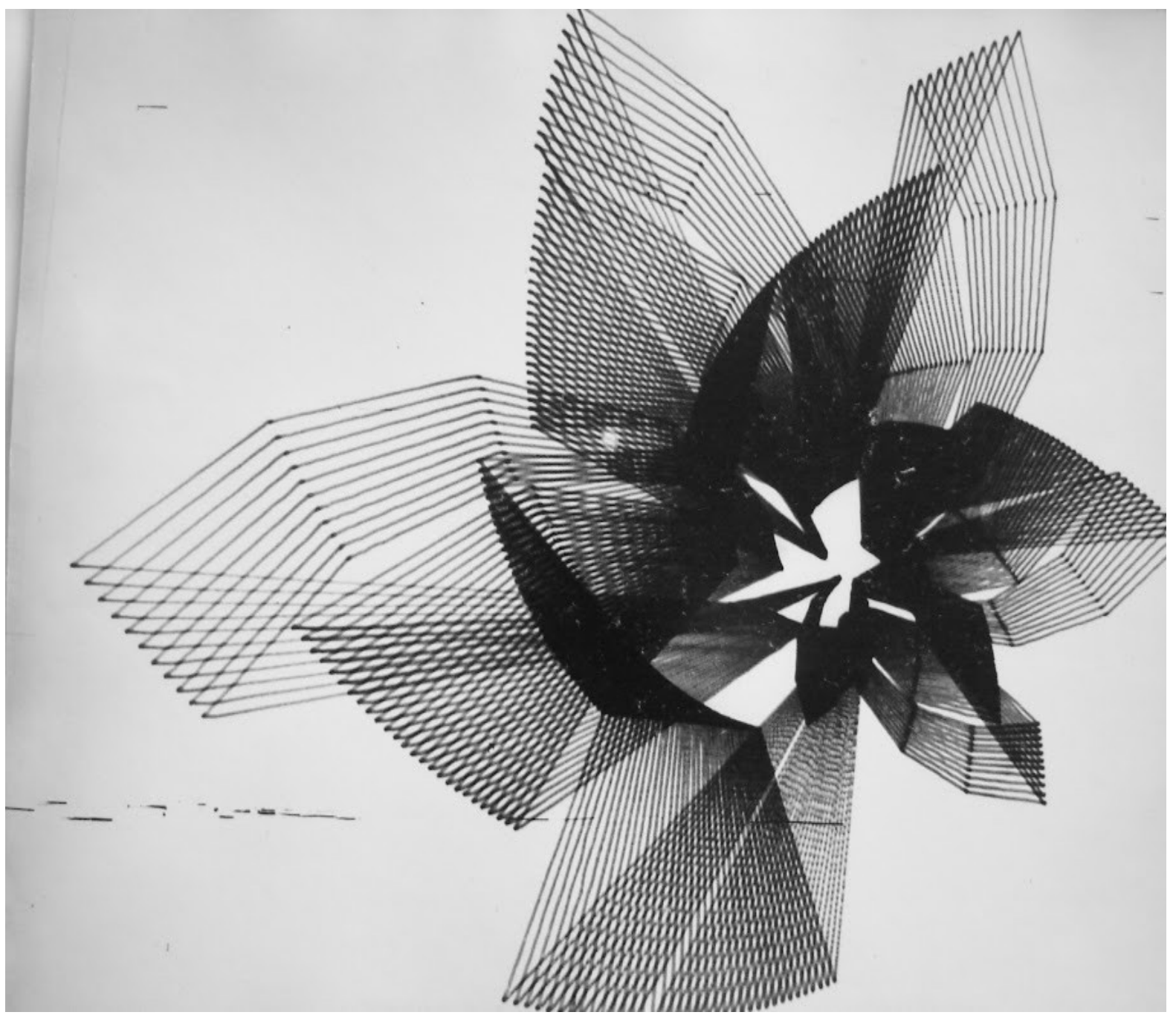



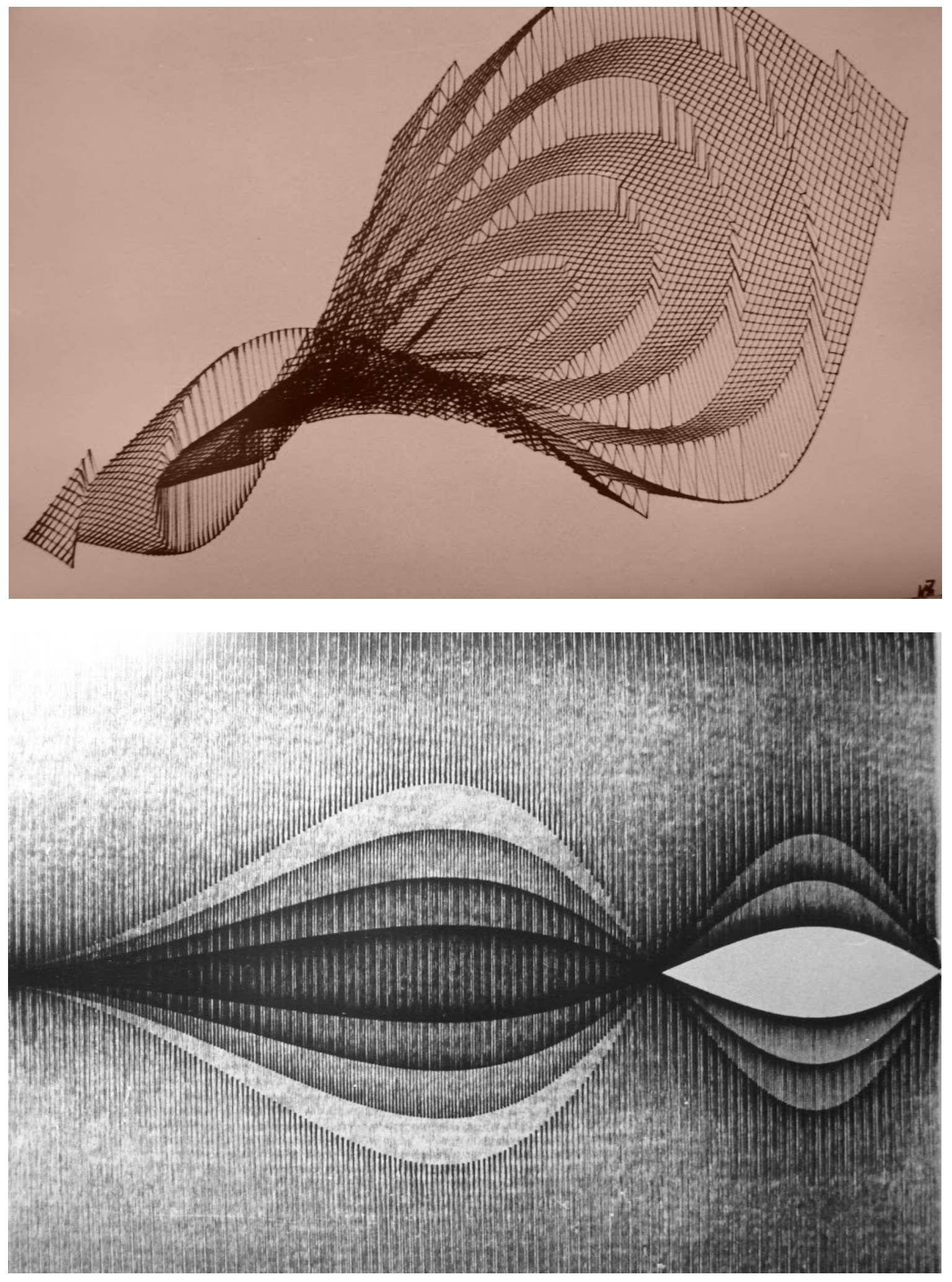

Studia UBB Digitalia, Volume 62, No. 2, 2017 


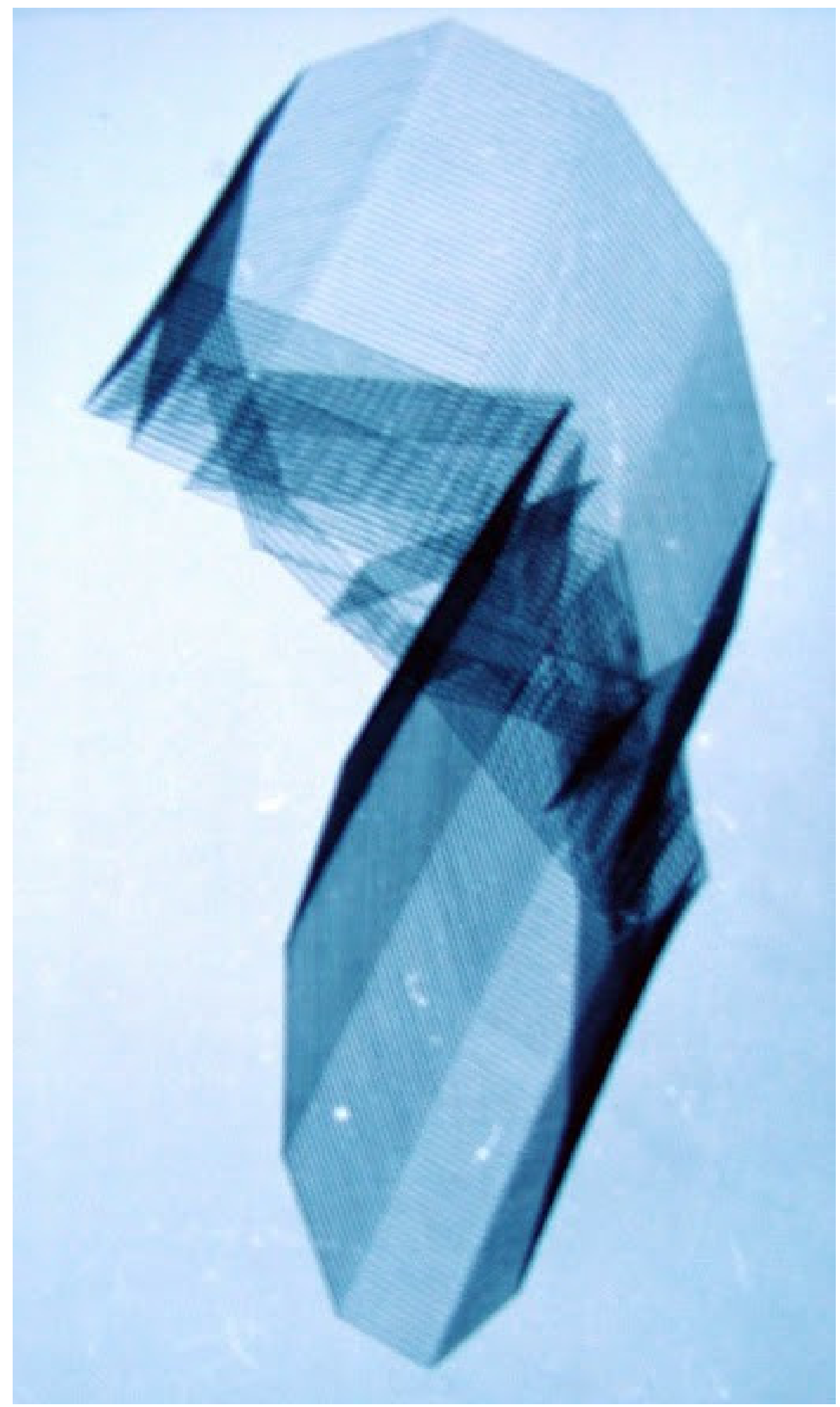




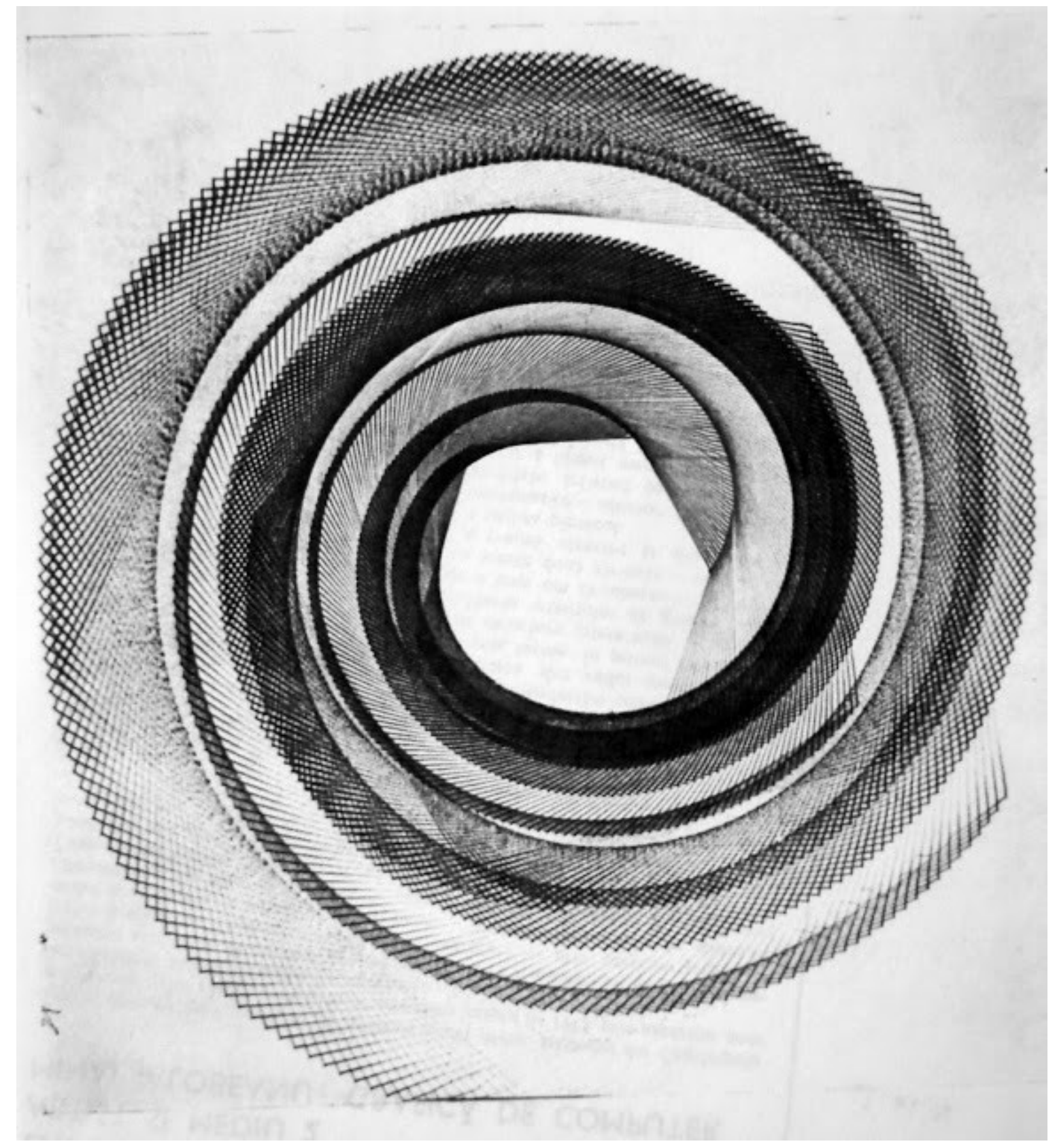

Studia UBB Digitalia, Volume 62, No. 2, 2017 


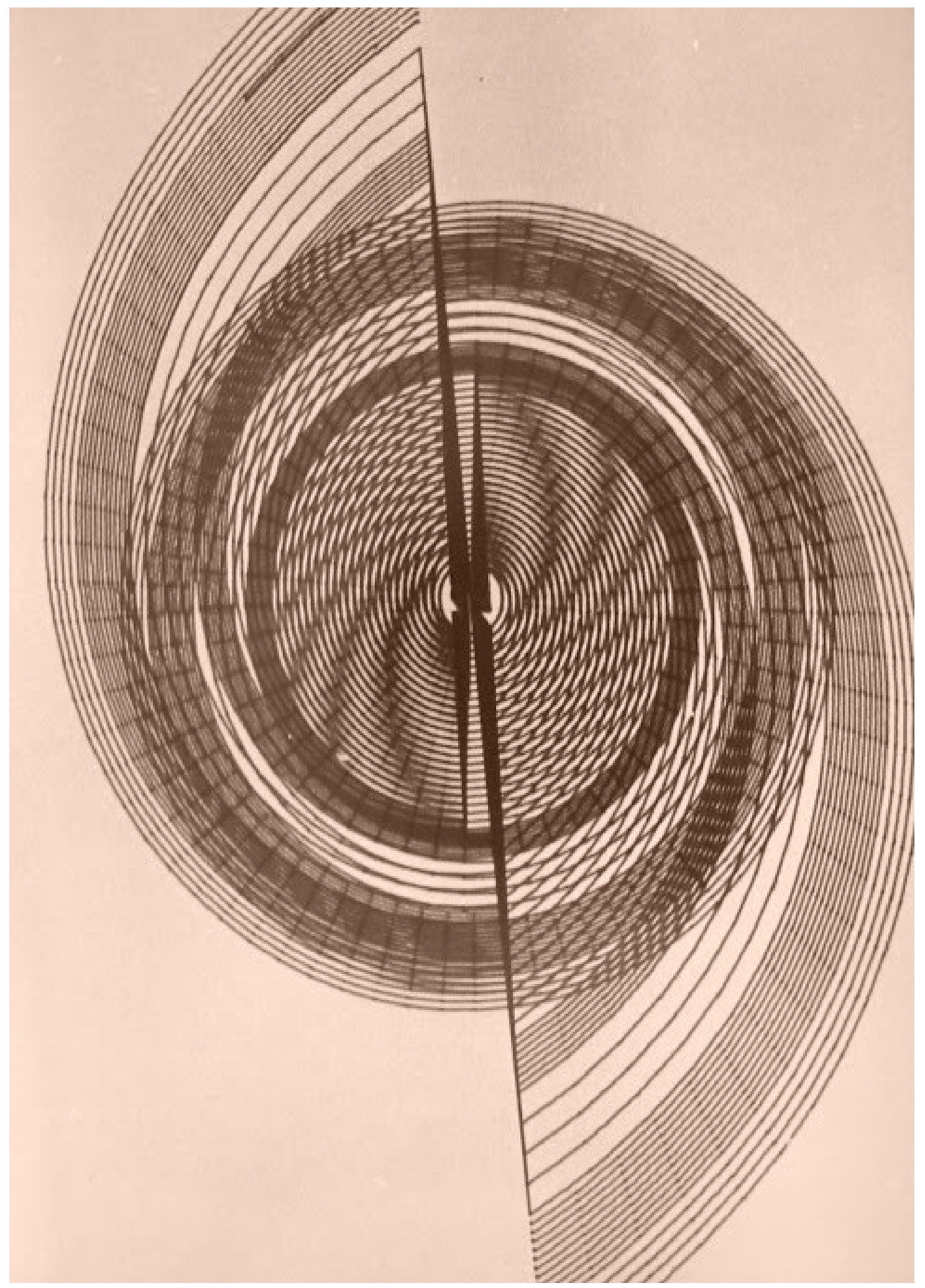




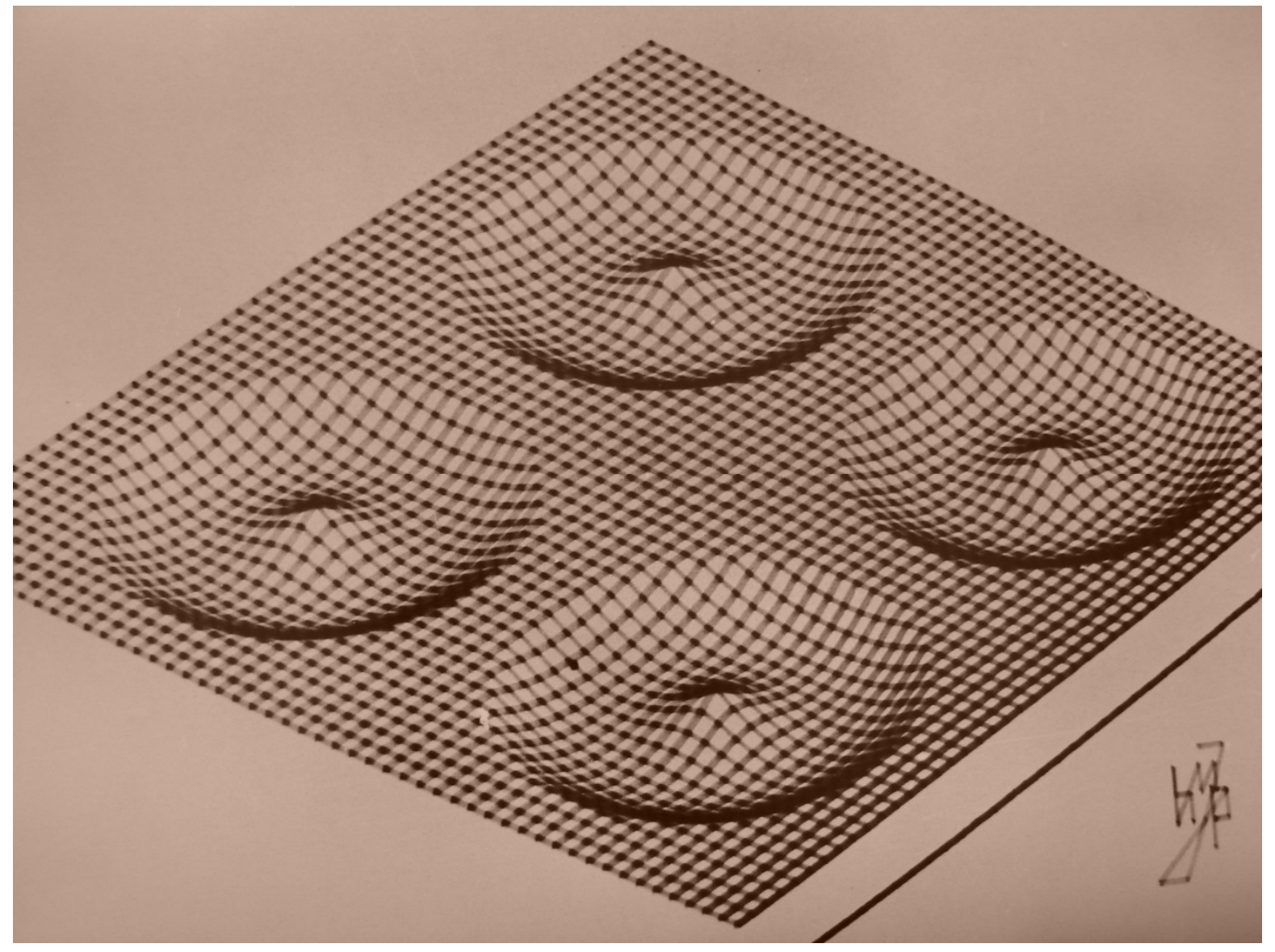

